\title{
The Effect of Single Parenthood on Girl Child Education in Kenema City
}

\author{
Stella Baindu Fortune
}

Masters in Educational Administration

Lecturer, Education Department, Eastern Polytechnic, Kenema, Eastern Region, Republic of Sierra Leone

\begin{abstract}
The study investigated the effect of single parenthood on girl child education.

A total of one hundred (100) single parents were randomly selected by an impartial ballot drawn from all the sections in Kenema city. Five areas were then selected including kpetema, Nyawama, kissy town, Samai Town and Lambayama sections. $20 \%$ of single parents in each section were used as sample for the topic under review. (The Effect of Single Parenthood on Girl Child Education).
\end{abstract}

\section{The findings of the study revealed that:}

There were more single parents who have never been married. This ranked up to the highest percentage than those who have cohabited, divorced and widowed.

Among the many reasons for the breakdown of marital relationships, failure to meet expectations and outside influences were the most paramount reasons. The other reasons, though may be important, but cannot stand as serious reasons for the breakdown of marital relationship.

The number of school going girls were more than the number of school going boys and there were less number of girls than boys that were not attending school.

Only few girls of single parents were performing excellently and few of them had completed tertiary level, some had completed senior secondary school level while a good number are yet to attain junior secondary school level.The highest percentage of the constraints that affected the academic performance of girls of single parents was peer-group influence and second highest being inadequate financial support. Among the coping mechanisms of single parents, were civil servants, petty traders and a reasonable number of single parents were barely managing to cope with their children's schooling.

Some parents suggested adequate sensitization for their school going girls, adequate job facilities for single parents, boarding home facilities and the establishment of single parenthood Association.

\section{Introduction}

Marriage is the naturally established institution that formally initiates a love-bond relationship between a man and a woman, and is expected to bring the two parties together in a free and everlasting union and start a family. People are often believed to enter into marriage relationship willingly and on the foundation of true love in the hope of sharing and enjoying a special companionship primarily to produce children and become parents so that parents in the marriage relationship nurse hopes of sharing in permanent romantic intimacy, and forever remain close friends to help, support and understand each other, without everyday problem and challenges, and even stand up for each other without regard to consequences.

However, in Sierra Leone, many people are known to have lived together without ever being married such that they could break up the marriage without any self- reproach and live as single parents. Also some young girls are forced into living together and even marrying as a result of such circumstances as inopportune pregnancy and financial hardship. Many of such relationships soon break up as new adjustments are made when the circumstances change to leave one of the partners as a single parenthood.

As the oldest and most widespread human institution, the family constitutes the body that provides moral, spiritual, economic and other needs to its members. The families in the Kenema Township are predominantly based on the extended family system where family relationships are largely based on kinship. Where the family members are affiliated not only by birth but also by marriage, by adoption and even by commonality of arrears of origin or parentage. Very few families in Kenema Township live in accordance with the Western style nuclear family system that excludes anybody outside of the father, the mother and their biological children.

The majority of the extended families in the Kenema Township often confine the girl child to performing the essential household duties, including helping the mother to provide food for the family, and taking care of the home and younger siblings. Consequently, girl child education is not given the emphasis that it deserves such that most girls are easily carried away by peer group influence and even worse with single parents. 
As a consequence of the above, the educational attainment of the girl child largely depends upon the socio-economic status of the parents. This situation may affect them in different communities. This is much more justifiable when conflict theories (Ogburn and Tibbits 1934) expressed that "the socio-economic status of a child's family will have a marked influence on his or her nutrition, health care, housing, educational opportunities, and in many respect, life changes as an adult"

The education of the girl child is clearly set out in the educational policy in Sierra Leone, with Non-Governmental organization (UNICEF) laying emphasis on this policy. Despite this declaration, most parents with particular reference to single parents in selected communities in the Kenema Township still confine the girl child to household chores and without good monitoring of the girl child's social and academic performance/achievement. These factors have greatly affected the educational attainment of the girl child in the Kenema Township and caused a lot of setbacks in their achievements or sometimes render them as unfortunate victims with no alternatives but to leave school as a teenage mother or do not attend school at all.

In subsequent years, little or no research has been carried out to determine the reasons for single parenthood and its effect on girl child education especially when the girl child education has become the concern of the nation through the Ministry of Education in Sierra Leone

\section{Research Objectives}

The main objectives of the research are:

i To investigate the causes of Single Parenthood.

ii To assess the performance of girls of single parents.

iii To investigate the constraints affecting the academic performance of girls of single parents.

iv To identify the coping mechanisms of single parents.

$\mathrm{v}$ To make suggestions and recommendations for single parents to enhance the education of their girl children.

\section{Methodology}

The study was carried out in five randomly selected Junior Secondary Schools in Kenema City, Nongowa Chiefdom in the Eastern Province, Republic of Sierra Leone. Kenema City is the capital of Kenema district and is a major economic center of the Eastern Province. Kenema City has a population of 200,354 in the 2015 Sierra Leone Census; And lies approximately 320 kilometers (200 miles) south East of Freetown and about 60 Kilometers (40 miles) south of Bo.

The city of Kenema is home to the Eastern Polytechnic which is the highest formal Learning institution in the city, offering degree and certificate courses.

The general method used for this research was based on investigative questionnaire - A survey sample estimate which was descriptive and analytical. Though the questions were not exhaustive, yet they cover specific areas to highlight and obtain relevant information relating to the objective of the study.

Inclusive of the questions were multiple choice questions and open ended questions. A total of one hundred (100) single parents were randomly selected by an impartial ballot drawn from all the sections in Kenema city. Five areas were then selected including kpetema, Nyawama, kissy town, Samai Town and Lambayama sections. $20 \%$ of single parents in each section were used as sample for the topic under review. (The Effect of Single Parenthood on Girl Child Education).

The instrument used to collect relevant data in relation to the topic were: well-structured and explicit questionnaire for each single parent; personal interview with non-literate single parents and single parents outside of the selected participants.

The data were analyzed using percentage, descriptive interpretations and summary by means of table for the data collected.

\section{Result and Discussion}

\section{Result}

a. Marital status of single parents interviewed

b. Reasons for single parenthood

c. Number of children attending and not attending school according to gender

d. Academic performance of girls in school

e. Educational attainment of girls of single parents

f. Constraints that affect the academic performance of girls of single parents

g. Coping mechanism of single parents

h. Suggestions from single parents.

4.1.0: Marital status of single parents interviewed Table No 01

\begin{tabular}{|l|c|c|}
\hline Marital Status & Frequency & Percentage (\%) \\
\hline Divorced & 20 & $20 \%$ \\
\hline Widowed & 10 & $10 \%$ \\
\hline Cohabited & 27 & $27 \%$ \\
\hline Never Married & 43 & $43 \%$ \\
\hline Total & 100 & $100 \%$ \\
\hline
\end{tabular}

Table 1: Revealed that $43 \%$ of respondents have never been married, while $27 \%$ had cohabited but now separated $20 \%$ had married but were then divorced and $10 \%$ having lost their husband or wives.

\subsubsection{Causes of single Parenthood}

Table 2

\begin{tabular}{|c|l|c|c|}
\hline No & $\begin{array}{l}\text { Causes of Single } \\
\text { Parenthood }\end{array}$ & Frequency & Percentage \\
\hline 1 & Poor financial support & 2 & $2 \%$ \\
\hline 2 & Poor sexual satisfaction & 3 & $3 \%$ \\
\hline 3 & Pursuit of careers & 4 & $4 \%$ \\
\hline 4 & Quarrelsomeness & 7 & $7 \%$ \\
\hline 5 & Conflict of gender roles & 9 & $9 \%$ \\
\hline 6 & Conflict of moral standards & 10 & $10 \%$ \\
\hline 7 & Wife battering and cruelty & 12 & $12 \%$ \\
\hline 8 & Adultery & 12 & $12 \%$ \\
\hline 9 & Failed expectations & 18 & $18 \%$ \\
\hline 10 & Outside influence & 23 & $23 \%$ \\
\hline & Total & 100 & $100 \%$ \\
\hline
\end{tabular}

Source: Data collected 2018 
Among the many reasons for the breakdown of marital relationship, Table 2 reveals that poverty and poor sexual satisfaction ranked the lowest $-2 \%$ and $3 \%$ respectively, while outside influence ranked the highest $23 \%$ and failure to meet expectation $18 \%$ being the second highest.

4.1.2 Number of children attending and not attending school according to gender.

Table 3

\begin{tabular}{|l|c|c|}
\hline No. of children attending school & Frequency & Percentage \\
\hline Boys & 52 & $30 \%$ \\
\hline Girls & 80 & $44 \%$ \\
\hline No. of children not attending school & \multicolumn{2}{|l|}{} \\
\hline Boys & 22 & $13.2 \%$ \\
\hline Girls & 18 & $10.4 \%$ \\
\hline Total & 40 & $100 \%$ \\
\hline
\end{tabular}

Source: Data collected 2018

Table 3: Revealed that $30 \%$ of boys and $44 \%$ of girls are attending school, While $13.2 \%$ of boys and $10.4 \%$ of girls are not attending school. This data indicate that there are more girls of single parents attending school than there are boys.

\subsection{Performance of girls of single parents in School}

\section{Table 4}

\begin{tabular}{|l|c|c|}
\hline Academic Performance & $\begin{array}{c}\text { Frequency } \\
(\mathbf{N o})\end{array}$ & $\begin{array}{c}\text { Percentage } \\
(\boldsymbol{\%})\end{array}$ \\
\hline Unsatisfactory & 41 & $51.4 \%$ \\
\hline Good & 26 & $32.2 \%$ \\
\hline Excellent & 13 & $16.4 \%$ \\
\hline Total & 80 & $100 \%$ \\
\hline
\end{tabular}

Source: Data collected 2018

Table 4: Reveals that $51.4 \%$ of girls performed unsatisfactorily, while $32.2 \%$ performed well and $16.4 \%$ performed excellent.

\subsubsection{Educational attainment of girls of single parents}

Table 5

\begin{tabular}{|l|c|c|}
\hline Level of attainment & Frequency (No) & Percentage \\
\hline Primary & 19 & $19 \%$ \\
\hline JSS & 26 & $26 \%$ \\
\hline SSS & 31 & $31 \%$ \\
\hline Tertiary & 24 & $24 \%$ \\
\hline Total & 100 & $100 \%$ \\
\hline
\end{tabular}

Source: data collected (2018)

As indicated in table 5, the highest percentage $(31 \%)$ of girls of single parents have completed senior Secondary School Level, $26 \%$ JSS, 24\% Tertiary and 19\% Primary Level. On the whole, the academic attainment of girls of single parents is unsatisfactory

4.3 Constraints that affect the academic performance of girls of single parents

Table 6

\begin{tabular}{|l|l|l|}
\hline Constraints & Frequency (No) & Percentage \\
\hline Poor parental attention & 11 & $14 \%$ \\
\hline Little time for studies & 15 & $19 \%$ \\
\hline Inadequate financial support & 22 & $27 \%$ \\
\hline Peer-group influence & 24 & $30 \%$ \\
\hline Others & 8 & $10 \%$ \\
\hline Total & 80 & $100 \%$ \\
\hline
\end{tabular}

Source: data collected (2018)
Table 6 reveals that the highest response for the constraints that affect academic performance of girls of single parents are peergroup influence 305 , inadequate financial support $27 \%$, Little time for studies with a percentage response of $19 \%$ and poor parental attention 14\%. Respondents revealed that the other unknown excuses should not be over looked as it is s contributing factor for the poor performance of girls of single parents in schools.

\subsection{Coping mechanism of single parents}

Table 7

\begin{tabular}{|l|c|c|}
\hline Coping mechanism & $\begin{array}{c}\text { Frequency } \\
\text { (No) }\end{array}$ & $\begin{array}{c}\text { Percentage } \\
(\mathbf{\%})\end{array}$ \\
\hline Civil Servant & 31 & $31 \%$ \\
\hline Petty trading & 29 & $29 \%$ \\
\hline Farmer & 08 & $8 \%$ \\
\hline Assistance from family members & 11 & $11 \%$ \\
\hline Others & 21 & $21 \%$ \\
\hline Total & 10 & $100 \%$ \\
\hline
\end{tabular}

Source: data collected (2018)

Table 7: Revealed that, among the total number of single parents interviewed, $31 \%$ are civil servants and $29 \%$ are petty traders, $11 \%$ received assistance from family members and only $8 \%$ are farmers. However, $21 \%$ responded as having no definite source of income.

Table 8: Suggestions from single parents

\begin{tabular}{|l|c|}
\hline Suggestion & Percentage \\
\hline Sensitization & $30 \%$ \\
\hline Adequate job facilities & $30 \%$ \\
\hline Boarding home facilities & $25 \%$ \\
\hline Establishment of single parenthood association & $15 \%$ \\
\hline
\end{tabular}

Source: data collected (2018)

Respondents revealed in table 8 that $30 \%$ of sensitization, $30 \%$ of adequate job facilities should be considered, while boarding home facilities and the establishment of single parents association must not be overlooked.

\section{Discussion}

5.1 Based on the result of the research, it was revealed that most of the single parents (men) were truly surrogate parents because they often had someone living with them and assisting them with care of the children although they were the true biological fathers of the children. On the other hand, most of the women respondents struggled alone with the care of their children with hardly anybody living with then to assist them.

From the survey of the marital status of single parents, $43 \%$ had never been married, $27 \%$ had cohabited, $20 \%$ were then divorced and 10 widowed. Respondents identified ten reasons that commonly lead to single parenthood; and listing these in order of frequency of occurrence, they included poverty, poor sexual satisfaction, pursuit of career, quarrelsomeness. Conflict of gender role, conflict of moral standards, wife battering and cruelty, adultery, failure to meet expectations and outside influences. It is interesting to realize that poverty and poor sexual satisfaction ranked lowest, while outside influences and failure to meet expectation ranked the highest and second highest respectively. One would have taught that the kenema city, currently wavering between a semi-rural and a cosmopolitan community, would have 
ranked either adultery or wife battering and cruelty as highest among the reason for the breakdown of relationships, but rather these ranked 7 th $(12 \%)$ and poverty being the least $2 \%$ of the reasons, explains to some extend how women who are single parents would cope to manage their situations.

In depth discussion, respondents revealed that while most women would rather cope with poverty and sexual dissatisfaction than with outside influence and failure to meet expectation, few men revealed that they are easily troubled by poverty and quarrelsomeness. Table 3 gives details of the total number of children attending and not attending school according to gender. It will be seen from Table 3 that school going children who are girls make up to 80 of the entire number of surviving children in the five communities studied, Of a total number of 98 girls, 80 were attending school, indicating that the single parents were concerned and committed to the education of their children. It was revealed in table 4 that $16.4 \%$ of the girls attending school were performing excellently and $32.2 \%$ performed well with potentials to pursue any career if given the required financial and moral support. On the contrary, $51 \%$ of the girls were academically performing unsatisfactory for whom urgent attention is required to help improve their situations. This is a clear manifestation that the situation of single parenthood has had negative effect on the education of the girl child.

Table 5 revealed that only $19 \%$ of the girls of single parents that were attending school have completed tertiary level, indicating that the academic attainment of girls was unsatisfactory. Subsequently, the unsatisfactory performance could not be dissociated from the adverse financial constraint on most single parents and their school going children. Although table 6 revealed that the highest among the constraint of single parents was peer-group influence (30\%) yet inadequate financial support and little time for studies that respectively accounted for $27 \%$ and $19 \%$ were great contributing factors for the unsatisfactory performance. Be as it May, the poor parental attention and other unknown factors should not be overlooked.

In respect of the coping mechanism of single parents, table 7 revealed that $30 \%$ were civil servants and $29 \%$ doing petty trading, while $21 \%$ were not employed and $11 \%$ receiving assistance from other family members. The inadequate job facilities therefore rendered parents incapacitated to support the education of their children. In lieu of this, their girl children could be easily carried away by peer-group influence and this may result to: dropping out from school at an early age, early marriage and teenage pregnancy that will increase the high rate of uneducated girls and single parenthood in Sierra Leone, which may have negative effect on the community and the nation in due course.

Furthermore, single parents suggested that there should be adequate sensitization for their school going girls, adequate job facilities for single parents, boarding home facilities and the establishment of single parenthood association.

\section{Conclusion and Recommendations}

\subsection{Conclusion}

The study concluded that:

Single parent mothers are faced with a lot of constraints than single parent fathers.
The general academic performance of girls of single is not encouraging.

The inadequate job facilities for single parents disenable them to fully support their girl's education.

Most single parents in the study areas are self-employed and are low income earners, which posed adverse financial constraints on them and their dependents.

Girls of single parents were much more opened to their peer-group member than to their parents.

Most girls do not have enough time to study at home due to overburdened domestic chores. This affects their general academic performance.

Though single parents are concerned and committed to the education of their girl children, yet they are not financially strong to meet the financial requirement towards their children's education.

\subsection{Recommendations}

The study recommended that:

I. Couples should endeavor to maintain marital relationships regardless the challenges they may be facing, so that they can unanimously handle and effectively control the problem of financial inadequacy and peer-group influence especially for their girl children.

II. The government through the ministry of Education should include sex education into the junior and Senior Secondary School's curriculum and to also invest in teenage pregnancy contraceptives to be available in all the schools.

III. There should be intensified counseling to people living in relationship especially couples. For if we preserve the relationship. We can help to improve on the general performance of our children.

IV. Parents should endeavor to effectively monitor their girl's day to day activities including social behaviors, the kind of friends they peer with and their academic performance most be frequently checked.

V. More School going girls should be encouraged through more incentives in the form of scholarships to cover tuitions, books, feeding and boarding schools.

VI. There must be effective communication between the school and the parents through regular Community Teachers Association (CTA) meetings.

VII. Parents must make sure that their girls are committed to study at home with little domestic duties to be performed

VIII. The Government of Sierra Leone through the Ministry of Education Youth \& sport must furnish the Technical Vocational Institution with necessary teaching or learning material to encourage learners who may happen to drop out from school; this will help reduce the dropout rate for our girls.

IX. Government and Non-Governmental Organizations create adequate job facilities to eradicate poverty in the country and to also cope with the economic trend of the country. 
X. It could be appropriate to look in to the performance of school going girls in general by conducting similar survey for all school going girls, so as to make a fair judgment in respect of the performance of girls without having to unnecessarily provoke resentments from single parents.

\section{Bibliography}

[1] Bee Lawrence, (1995) marriage and Family

[2] Biel by and Biel by, (1992)-Bachelor Life includes a family

[3] Fromm Eric, (1994) - Man for Himself

[4] Greenfield Suzuki, (19980 - One Parent Family

[5] Kristin Lurker, (1996)- Abortion and the politics of motherhood
[6] Maming Baruth, (1996)- A personal reading of the research literature

[7] Richardson, et al (2001)- The impact of family structure and family change on child outcome

[8] Rossi Alice, (1968) - Transition to parenthood -Journal of marriage and the family.

[9] Seiko Matsuba, (1998)- Social Policy Journal of New Zealand

[10] Sigall, (1998) - Public and private Families

[11] Thomson and Colella, (1992) - Single parent Kids more at risk

[12] The Holy Bible, -2nd Book of Corinthians Chapter 5 verse 8-9

[13] The Internet - (www.umarried.org)

[14] William F. Oburn, (1996)- The family and its funtion 